\title{
Fine root distribution, seasonal pattern and production in four plantations compared with a natural forest in Subtropical China
}

\author{
Yu-Sheng YANG ${ }^{a *}$, Guang-Shui CHEN ${ }^{\mathrm{a}}$, Peng LIN ${ }^{\mathrm{b}}$, Jin-Sheng XIE ${ }^{\mathrm{c}}$, Jian-Fen GUO \\ ${ }^{a}$ Dept. of Geography Science, Fujian Normal University, Fuzhou 350007, China \\ $\mathrm{b}$ Dept. of Life Science, Xiamen University, Xiamen 361005, China \\ ${ }^{c}$ Dept. of Forestry, Fujian Agriculture and Forestry University, Fuzhou 350002, China
}

(Received 12 May 2003; accepted 20 August 2003)

\begin{abstract}
Fine root (<2 mm in diameter) distribution, seasonal pattern and net production were studied during 1999-2001 in 33 year-old plantations of two coniferous trees, Chinese fir (Cunninghamia lanceolata, CF) and Fokienia hodginsii (FH) and two broadleaved trees, Ormosia xylocarpa (OX) and Castanopsis kawakamii (CK), and compared with that of an adjacent natural forest of Castanopsis kawakamii (NF, $\sim 150$ year old) in Sanming, Fujian, China. Fine root biomass and necromass were determined by soil coring at a bimonthly interval. Soil cores were divided into 10 depths: $0 \sim 10,10 \sim 20,20 \sim 30,30 \sim 40,40 \sim 50,50 \sim 60,60 \sim 70,70 \sim 80,80 \sim 90$, and $90 \sim 100 \mathrm{~cm}$. Litter bags $\left(18 \times 18 \mathrm{~cm}^{2}\right.$ size, $0.25 \mathrm{~mm}$ mesh) were used in determination the decay rates of fine roots $(<0.5 \mathrm{~mm}, 0.5-1 \mathrm{~mm}$, and $1-2 \mathrm{~mm})$. Mean annual fine-root production, mortality, decomposition and turnover rate were calculated by the compartment-flow method. Mean fine-root biomass ranged from $1.49 \mathrm{Mg} \mathrm{ha}^{-1}$ in the $\mathrm{CF}$ to $4.94 \mathrm{Mg} \mathrm{ha}^{-1}$ in the NF, and decreased in the following order: $\mathrm{NF}>\mathrm{CK}>\mathrm{FH}>\mathrm{OX}>\mathrm{CF}$. There were significant seasonal changes of biomass and necromass in all stands $(P<0.05)$, while no significant yearly fluctuations were detected $(P>0.05)$. In all stands, an early spring (March) peak of fine root biomass was found, and the minimum value occurred mainly in dry summer or cold winter. For the NF, 59.8\% of fine root biomass was found in the top soil of $0-10 \mathrm{~cm}$, a layer that maximum difference of depth distribution among all stands occurred, where fine root biomass of the NF was 2.37 times, 3.55 times, 8.12 times, and 7.12 times as much as those of the $\mathrm{CK}, \mathrm{FH}, \mathrm{CF}$, and $\mathrm{OX}$, respectively. Percentages of original mass lost during the first year of decomposition ranged from $43 \%$ to $56 \%$ for the FH to $68 \%$ to $80 \%$ for the NF. Mean annual root decomposition, mortality and production ranged from $8.47 \mathrm{Mg} \mathrm{ha}^{-1} \mathrm{a}^{-1}, 8.63 \mathrm{Mg} \mathrm{ha}^{-1} \mathrm{a}^{-1}$ and $9.5 \mathrm{Mg} \mathrm{ha}^{-1} \mathrm{a}^{-1}$ in the NF to $2.50,2.49$ and $2.51 \mathrm{Mg} \mathrm{ha}^{-1} \mathrm{a}^{-1}$ in the $\mathrm{CF}$, ranked as NF $>\mathrm{CK}>\mathrm{FH}>\mathrm{OX}>\mathrm{CF}$. The mean root turnover rate ranged from $1.48 \mathrm{a}^{-1}$ in the FH to $1.78 \mathrm{a}^{-1}$ in the NF.
\end{abstract}

fine root / seasonal pattern / root distribution / root production / root mortality / root turnover / natural forest / monoculture plantation

Résumé - Répartition et production de radicelles et évolutions saisonnières dans quatre plantations en comparaison avec une forêt naturelle, en Chine tropicale. La répartition, l'évolution selon les saisons et la production nette de radicelles $(<2 \mathrm{~mm}$ en diamètre) ont été étudiées de 1999 à 2001 dans deux plantations âgées de 33 ans de deux conifères, le sapin de Chine (Cunninghamia lancolata, CF) et Fokienia hodginsii $(\mathrm{FH})$ ainsi que dans deux plantations de feuillus, Ormosia xylocarpa (OX) et Castanopsis kawakamii (CK). Celles-ci ont été comparées à une forêt naturelle voisine de Castanopsis kawakamii (NF, 150 ans) à Samming, Fujian, Chine. La biomasse et la nécromasse de radicelles ont été obtenues par carottage dans le sol effectué deux fois par mois. Les carottes de sol ont été divisées en 10 éléments selon la profondeur : $0 \sim 10,10 \sim 20,20 \sim 30,30 \sim 40,40 \sim 50,50 \sim 60,60 \sim 70,70 \sim 80,80 \sim 90$, et $90 \sim 100 \mathrm{~cm}$. On a utilisé des sacs à litière $\left(18 \times 18 \mathrm{~cm}^{2}\right.$, maille de $\left.0,25 \mathrm{~mm}\right)$ pour déterminer le taux de décomposition des radicelles $(<0,5 \mathrm{~mm}, 0,5-1 \mathrm{~mm}, 1-2 \mathrm{~mm})$. Les taux de production moyenne annuelle, de mortalité, de décomposition et de turnover des radicelles ont été calculés par la méthode de « compartment flow ». La biomasse moyenne de radicelles va de $1,49 \mathrm{Mg} /$ ha dans le CF à 4,94 Mg/ha pour le NF; elle décroît dans l'ordre suivant : NF $>$ CK $>$ $\mathrm{FH}>\mathrm{OX}>\mathrm{CF}$. On a enregistré des différences significatives de biomasse et nécromasse, selon les saisons dans tous les peuplements $(P<0,05)$, tandis qu'aucune fluctuation n'a pu être mise en évidence entre années $(P>0,05)$. Pour tous les peuplements, on enregistre un pic de biomasse de radicelles au début du printemps (mars), les valeurs minimum intervenant au cours d'étés secs ou d'hivers froids. Pour le NF, 59,8 \% de la biomasse de radicelles se situe dans la zone superficielle du sol $(0-10 \mathrm{~cm})$ où les différences de biomasse de radicelles entre peuplements sont les plus marquées, les valeurs pour NF étant respectivement 2,37 fois, 3,55 fois, 8,12 fois et 17,12 fois plus élevées que celles de CK, FH, CF, et OX. Les pourcentages de la biomasse d'origine, perdue pendant la première année de décomposition, vont de $43 \%$ à $56 \%$ pour FH, de 68 à $80 \%$ pour NF. Les moyennes annuelles de décomposition, mortalité et production des racines s'étagent entre $8,47 \mathrm{Mg} \mathrm{ha}^{-1} \mathrm{a}^{-1}, 8,63 \mathrm{Mg} \mathrm{ha}^{-1} \mathrm{a}^{-1}$ et $9,5 \mathrm{Mg} \mathrm{ha}^{-1} \mathrm{a}^{-1}$ dans le NF à $2,50,2,49$ et $2,51 \mathrm{Mg} \mathrm{ha}^{-1} \mathrm{a}^{-1}$ pour le $\mathrm{CF}$, avec par ordre décroissant, NF $>\mathrm{CK}>\mathrm{FH}>\mathrm{OX}>\mathrm{CF}$. Le taux de turnover de racines va de $1,48 \mathrm{a}^{-1}$ pour FH à $1,78 \mathrm{a}^{-1}$ pour NF.

radicelle / variation saisonnière / répartition des racines / production racinaire / mortalité racinaire / turnover racinaire / forêt naturelle / plantation en monoculture

\footnotetext{
* Corresponding author: geoyys@ fjnu.edu.cn; gshuichen@ 163.com
} 


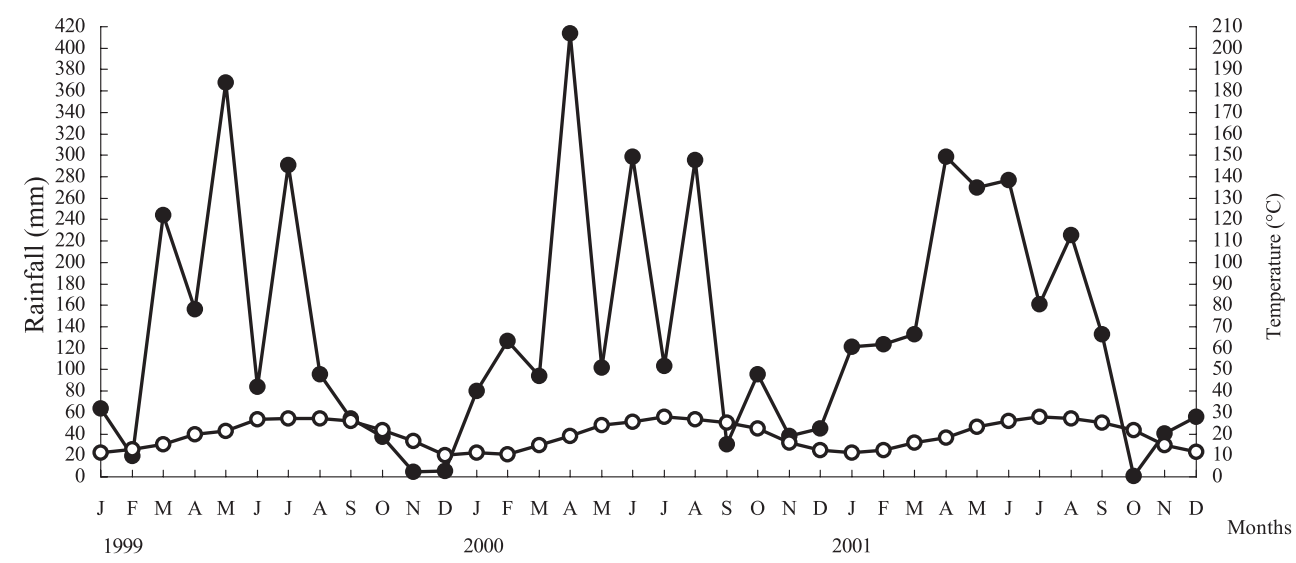

Figure 1. Temperature and rainfall patterns for the study area. $\bullet$ Monthly rainfall; $\bigcirc$ Monthly mean temperature.

\section{INTRODUCTION}

Fine root productivity often exceeds aboveground productivity in forest ecosystems, despite the fact that live fine root biomass constitutes only a small fraction of total stand biomass $[8,11,15,22,28,35]$. It is widely recognized that the turnover and decomposition of fine roots and associated mycorrhizae may contribute substantially more to soil organic matter (SOM) and nutrient pools than do aboveground litter-fall inputs $[1,7$, $11,22,35]$. Despite a wealth of information on fine roots in different forest ecosystems of the world has been compiled, largely in temperate and tropical forests, a relative few studies were carried out in forests of southern China, an area of the most important world subtropical forests.

In southern China, where high rainfall, steep slopes, and fragile soil are characteristic, large-scale of native forests have been converted to monoculture plantations (mainly economical conifers) following forest land clear-cutting, slash burning, and soil preparation. Yield decline and land deterioration have become noticeable during this conversion, and how to maintenance of soil fertility in these managed plantations has received considerable attention [41-43]. Currently, there is little known about the effects of forest conversion on fine root dynamics. The establishment of tree species trials during 1960s at the Xinkou Experimental Forestry Centre in south-eastern China provided a unique opportunity to examine how tree plantations altered fine root performance.

The objective of this study was initiated to determine in four plantation forests of Cunninghamia lanceolata (Chinese fir, $\mathrm{CF})$, Fokienia hodginsii (FH), Ormosia xylocarpa (OX) and Castanopsis kawakamii (CK), and an adjacent natural forest of Castanopsis kawakamii (NF): (1) fine-root biomass, distribution and seasonal patterns; and (2) fine-root production and mortality.

\section{MATERIALS AND METHODS}

\subsection{Site descriptions}

The study was carried out from January 1999 to December 2001 in the Xiaohu work-area of the Xinkou Experimental Forestry Centre of Fujian Agricultural and Forestry University, Sanming, Fujian, China ( $\left.26^{\circ} 11^{\prime} 30 \mathrm{~N}, 117^{\circ} 26^{\prime} 00 \mathrm{E}\right)$. It borders the Daiyun Mountain on the southeast, and the Wuyi Mountain on the northwest. The region has a middle subtropical monsoonal climate, with a mean annual temperature of $19.1{ }^{\circ} \mathrm{C}$ and a mean relative humidity of $81 \%$. The mean annual precipitation is $1749 \mathrm{~mm}$, mainly occurring from March to August (Fig. 1). Mean annual actual evapotranspiration is $1585 \mathrm{~mm}$ $[38,40]$. The growing season is relatively long with an annual frostfree period of around 330 days. The parent material of the soil is acid sandy shale and soils are classified as red soil (humic Planosols in FAO system). Thickness of the soil usually exceeds $1.0 \mathrm{~m}$. In 1999, five $20 \times 20 \mathrm{~m}^{2}$ plots per forest were randomly established at the mid-slope position of the $\mathrm{CF}, \mathrm{FH}, \mathrm{OX}, \mathrm{CK}$, and NF.

Selected forest characteristics and some properties of the surface soil $(0-20 \mathrm{~cm})$ of the five sites are described in Table I [40].

The NF represents the evergreen, broadleaved $C$. kawakamii forest in mid-subtropical China with high purity ( $85 \%$ of total stand basal area for C. kawakamii), old age ( 150 year), and large area $(\sim 700$ ha) $[18,46]$. The floristic composition is very abundant (total 139 species in a $3100 \mathrm{~m}^{2}$ quadrate). In addition to $C$. kawakamii, the overstory also contained other tree species, such as Pinus massoniana, Schima superba, Lithocarpus glaber, Symplocos caudate, Machilus velatina, Randia cochinchinensis, and Symplocos stellaris. In 1966, part of this NF was clear-cut, slashed and burned. In 1967, the soil was prepared by digging holes and then 1-year-old seedlings of $C$. lanceolata (Chinese fir), F. hodginsii, O. xylocarpa, and C. kawakamii were planted with density of 3000 trees per hectare.

\subsection{Methods}

\subsubsection{Extraction of fine roots}

Fine root biomass was measured by the sequential core method. On each sampling date, six soil cores (1 $\mathrm{m}$ in depth) were randomly collected from each plot (30 per forest) bimonthly during January 1999 January 2002 using a steel corer (6.8 cm diameter, $1.2 \mathrm{~m}$ length). To avoid length shrinkage caused by soil compaction, each core was taken by three consecutive coring at the same sampling point, viz. $0-40 \mathrm{~cm}$, $40-80 \mathrm{~cm}$, and $80-100 \mathrm{~cm}$, respectively for each coring. Soil cores were then cut into different depths $(0 \sim 10,10 \sim 20,20 \sim 30,30 \sim 40$, $40 \sim 50,50 \sim 60,60 \sim 70,70 \sim 80,80 \sim 90$, and $90 \sim 100 \mathrm{~cm}$ ) and store at $4{ }^{\circ} \mathrm{C}$ in refrigerators until processed. Cores were washed with tap water to remove adhering soil and accompanying organic debris. 
Table I. Forest characteristics and soil properties of the NF, CK, FH, CF, and OX stands.

\begin{tabular}{|c|c|c|c|c|c|}
\hline \multirow{2}{*}{ Parameters } & \multicolumn{5}{|c|}{ Forest type $^{1}$} \\
\hline & $\mathrm{CF}$ & FH & OX & $\mathrm{CK}$ & $\mathrm{NF}^{2}$ \\
\hline Mean tree age (year) & 33 & 33 & 33 & 33 & $\sim 150$ \\
\hline Mean tree height (m) & 21.9 & 21.4 & 18.4 & 18.9 & 24.3 \\
\hline Mean tree diameter at breast height $(\mathrm{cm})$ & 23.3 & 21.6 & 17.2 & 24.2 & 42.2 \\
\hline Stand density $\left(\right.$ stem ha $\left.{ }^{-1}\right)$ & 1117 & 975 & 1109 & 875 & 255 \\
\hline Stand volume $\left(\mathrm{m}^{3} \mathrm{ha}^{-1}\right)$ & 425.91 & 379.57 & 209.01 & 412.43 & 398.31 \\
\hline Standing biomass of forest floor (mean $\pm \mathrm{sd}, \mathrm{Mg} \mathrm{ha}^{-1}$ ) & $3.15 \pm 0.68$ & $2.65 \pm 0.81$ & $7.22 \pm 1.38$ & $7.44 \pm 1.54$ & $7.72 \pm 1.86$ \\
\hline \multicolumn{6}{|l|}{ Soil (A horizon, 0-20 cm depth, mean $\pm \mathrm{sd}^{3}$} \\
\hline Bulk density $\left(\mathrm{g} \mathrm{cm}^{-3}\right)$ & $1.20 \pm 0.09$ & $1.13 \pm 0.10$ & $1.15 \pm 0.10$ & $1.10 \pm 0.12$ & $0.93 \pm 0.08$ \\
\hline Organic C (mg g $\left.{ }^{-1}\right)$ & $16.9 \pm 3.1$ & $17.7 \pm 2.5$ & $17.5 \pm 2.4$ & $17.1 \pm 2.0$ & $26.4 \pm 3.0$ \\
\hline Total N (mg g $\left.{ }^{-1}\right)$ & $1.12 \pm 0.28$ & $1.37 \pm 0.22$ & $1.29 \pm 0.19$ & $1.12 \pm 0.23$ & $1.88 \pm 0.20$ \\
\hline $\mathrm{C} / \mathrm{N}$ ratio & $15.1 \pm 2.1$ & $12.9 \pm 1.8$ & $13.6 \pm 2.3$ & $15.3 \pm 2.2$ & $14.0 \pm 2.5$ \\
\hline Hydrolyzable $\mathrm{N}\left(\mathrm{mg} \mathrm{g}^{-1}\right)$ & $0.11 \pm 0.02$ & $0.12 \pm 0.02$ & $0.13 \pm 0.01$ & $0.12 \pm 0.02$ & $0.14 \pm 0.03$ \\
\hline Available P $\left(\mathrm{mg} \mathrm{kg}^{-1}\right)$ & $4.7 \pm 0.8$ & $5.6 \pm 0.9$ & $6.8 \pm 1.3$ & $5.9 \pm 1.1$ & $7.6 \pm 1.4$ \\
\hline Available $\mathrm{K}\left(\mathrm{mg} \mathrm{kg}^{-1}\right)$ & $100 \pm 7$ & $108 \pm 9$ & $109 \pm 11$ & $121 \pm 9$ & $140 \pm 15$ \\
\hline $\mathrm{CEC}\left(\mathrm{cmol} \mathrm{kg}^{-1}\right)$ & $11.4 \pm 0.3$ & $11.9 \pm 0.3$ & $12.2 \pm 0.2$ & $12.9 \pm 0.3$ & $13.5 \pm 0.8$ \\
\hline Exchangeable bases $\left(\mathrm{cmol} \mathrm{kg}^{-1}\right)$ & $2.5 \pm 0.4$ & $3.2 \pm 0.4$ & $3.3 \pm 0.3$ & $3.8 \pm 0.6$ & $4.4 \pm 0.5$ \\
\hline Base saturation $(\%)$ & $22 \pm 3$ & $27 \pm 4$ & $27 \pm 3$ & $29 \pm 4$ & $32 \pm 3$ \\
\hline Soil $\mathrm{pH}$ in water & $4.8 \pm 0.3$ & $5.1 \pm 0.3$ & $5.1 \pm 0.2$ & $5.3 \pm 0.3$ & $5.8 \pm 0.3$ \\
\hline Leaf-litter decomposition constant $(k)\left(\mathrm{a}^{-1}\right)$ & 1.16 & 3.92 & 4.62 & 4.46 & 4.52 \\
\hline
\end{tabular}

${ }^{1} \mathrm{CF}$, Chinese fir (Cunninghamia lanceolata) plantation forest; FH, Fokienia hodginsii plantation forest; OX, Ormosia xylocarpa plantation forest; CK, Castanopsis kawakamii plantation forest; NF, natural forest of $C$. kawakamii. The abbreviations are the same as elsewhere.

${ }^{2}$ Castanopsis kawakamii is only involved.

${ }^{3}$ Six soils were randomly taken from each plot, totaled 30 soil samples per forest (5 plots per stand).

Fine roots were classified by diameter class $(<0.5 \mathrm{~mm}, 0.5-1 \mathrm{~mm}$, and 1-2 $\mathrm{mm}$ ), trees or undergrowth (shrubs and herbages), and physiological status (live or dead) based on color, texture and shape of the root $[11,22,28]$. Only fine roots of trees were collected and included in this study. In addition to those of $C$. kawakamii, fine roots of the NF included those of other species in the overstory. All fine root samples were oven-dried $\left(80^{\circ} \mathrm{C}\right)$ to constant weight and weighed.

The dry weight of living fine roots (root biomass) or dead fine roots (root necromass) was calculated using the following formula [22]:

Fine root biomass (or root necromass) $\left(\mathrm{Mg} \mathrm{ha}^{-1}\right)=$ dry weight of living (or dead) fine roots per core $(\mathrm{g}) \times 10^{-6} /(\pi 6.8(\mathrm{~d} / \mathrm{cm}) / 2)^{2} \times 10^{8}$.

\subsubsection{Fine root decomposition}

The litterbag technique was used to quantify the decomposition rate of fine roots. The fine roots of tree species were collected from each stand by sieving from the top $0-20 \mathrm{~cm}$ soil. In the NF, only roots of C. kawakamii were collected for decomposition. Roots were gently and briefly washed in tap water to remove adhering soil particles and spread on a laboratory table to dry for $24 \mathrm{~h}$ at room temperature [23], and then sorted into three size classes: $<0.5 \mathrm{~mm}, 0.5-1 \mathrm{~mm}$, and 1-2 mm. Roots which were clearly dead or decaying were discarded and only roots which appeared live at the time of collection were included in the litter bags.

In May 1999, the nylon litter bags $\left(18 \times 18 \mathrm{~cm}^{2}\right.$ size and $0.25 \mathrm{~mm}$ mesh) containing $5 \mathrm{~g}$ air-dried root samples (a total of $240 \mathrm{bags}$ were placed at each forest site, 80 for each size) were placed on the sites at a soil depth of $10 \mathrm{~cm}$ at random locations for an 24 months period.
Six bags were retrieved at random for each diameter class from each forest site after $30,60,90,150,210,270,330,390,540,630$, and 720 days of sample placement. Immediately after collection, the litter bags were placed in individual polyethylene bags and transported to the laboratory. The residual materials were carefully separated from the bags, cleaned of adhering plant parts and soil particles, oven-dried to constant mass at $60{ }^{\circ} \mathrm{C}$, and weighed.

\subsubsection{Calculations and statistical analysis}

The model for dry mass loss was represented by the following equation [23]:

$$
x_{t} / x_{0}=100 \exp (-k t)
$$

where $x_{t}$ is the dry mass remaining at time $t, x_{0}$ is the initial weight, $k$ is the decay constant, and $t$ is the time.

Fine root production, mortality, and decomposition were calculated with the compartment-flow method, according Kurz and Kimmins [14]:

$$
\begin{gathered}
\mathrm{LFR}_{t}=\mathrm{LFR}_{t-1}+\mathrm{P}_{t}-\mathrm{M}_{t} \\
\mathrm{DFR}_{t}=\mathrm{DFR}_{t-1}+\mathrm{M}_{t}-\mathrm{D}_{t} \\
\mathrm{D}_{t}=\left(\mathrm{DFR}_{t-1}+\mathrm{M}_{t}\right) \mathrm{DR}
\end{gathered}
$$

where $\mathrm{LFR}_{t}, \mathrm{DFR}_{t}, \mathrm{P}_{t}, \mathrm{M}_{t}$, and $\mathrm{D}_{t}$ is fine root biomass (living roots), root necromass (dead roots), production, mortality, and decomposition, respectively, at t interval, and DR is root decay rate. Then, annual 
fine root production $(\mathrm{P})$, mortality $(\mathrm{M})$, and decomposition (D) can be calculated as following:

$$
\begin{aligned}
\mathrm{P} & =\Sigma \mathrm{P}_{t}, \\
\mathrm{M} & =\Sigma \mathrm{M}_{t}, \\
\mathrm{D} & =\Sigma \mathrm{D}_{t} .
\end{aligned}
$$

The turnover rate and the mean residence time of fine roots were calculated by the following equation:

Turnover rate $\left(\mathrm{a}^{-1}\right)=$ Annual root production $\left(\mathrm{Mg} \mathrm{ha}^{-1} \mathrm{a}^{-1}\right) /$ Mean root biomass $\left(\mathrm{Mg} \mathrm{ha}^{-1}\right)$.

Mean residence time $(\mathrm{a})=$ Mean root biomass $\left(\mathrm{Mg} \mathrm{ha}^{-1}\right) /$ Annual root production $\left(\mathrm{Mg} \mathrm{ha}^{-1} \mathrm{a}^{-1}\right)$.

The biomass data were analyzed by one- and two-way analysis of variance with the Statistical Program for Social Science (SPSS 10.0) software to determine differences between seasons and between years, and Newman-Keuls tests were performed for comparisons of mean values (signification for $P<0.05$ ).

\section{RESULTS}

\subsection{Fine root biomass and necromass}

There were significant differences in root biomass and necromass among stands $(P<0.05)$, except between the $\mathrm{OX}$ and the $\mathrm{CF}(P>0.05)$. Mean fine root biomass during the 3 -year measurement period ranged from $1.48 \mathrm{Mg} \mathrm{ha}^{-1}$ in the CF to $4.94 \mathrm{Mg} \mathrm{ha}^{-1}$ in the NF, and decreased in the following order: $\mathrm{NF}>\mathrm{CK}>\mathrm{FH}>\mathrm{OX}>\mathrm{CF}$. Mean fine root necromass varied annually from $1.29 \mathrm{Mg} \mathrm{ha}^{-1}$ in the $\mathrm{CF}$ to $3.56 \mathrm{Mg} \mathrm{ha}^{-1}$ in the $\mathrm{NF}$, and can be ranked as NF $>\mathrm{CK}>\mathrm{FH}>\mathrm{OX}>\mathrm{CF}$. The contribution of $<0.5 \mathrm{~mm}$ (very fine roots) roots to total fine root biomass ranged from $29.4 \%$ in the CK to $62.2 \%$ in the FH. The ratio of root necromass to root biomass is quite invariable and ranged from 0.72 in the NF to 0.87 in the CF (Tab. II).

\subsection{Seasonal patterns}

Seasonal differences in fine root biomass and in necromass were significant $(P<0.05)$ in all stands, while there was no significant difference detected between years in any stand $(P>$ 0.05) (Fig. 2). The seasonal patterns of root biomass and necromass were quite similar among the five stands. A peak of root biomass occurred in March in all stands, and the CF stand showed also a particular significant higher value in September (Fig. 2). However, there was a difference in the timing of lowest value among stands, mainly occurred during May-July or November-January. The maximum root necromass occurred in May or July, except in the OX stand (September or November) (Fig. 2), coinciding approximately with the peaks of maximum rainfall.

\subsection{Vertical distribution}

The depth distribution of root biomass varied among stands (Fig. 3). Fine root biomass was more evenly distributed in soil profiles in the OX and $\mathrm{CF}$ than in the NF, CK, and FH. The maximum difference occurred in the top 0-10 cm layer, where the root biomass of the NF was up to $2.95 \mathrm{Mg} \mathrm{ha}^{-1}$, being 2.37 time, 3.55 times, 8.12 times, and 7.12 times as much as that of $\mathrm{CK}$,
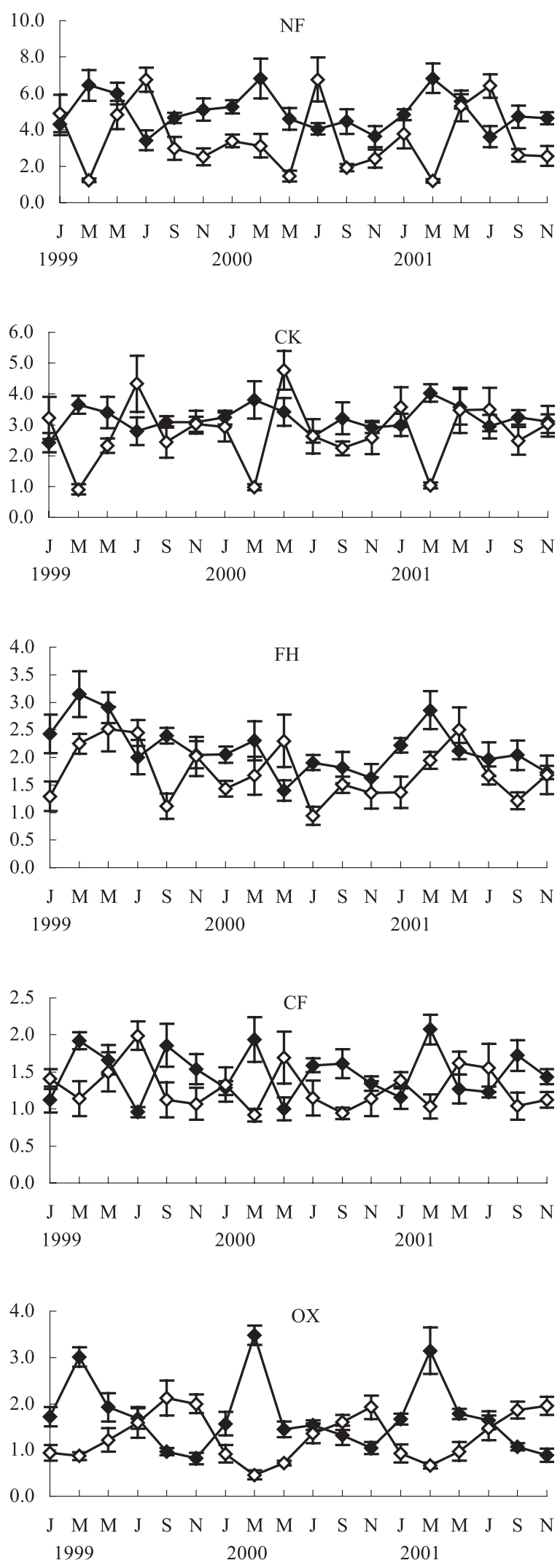

Figure 2. Seasonal patterns of fine root biomass and necromass $\left(\mathrm{Mg} \mathrm{ha}^{-1}\right)$ in the NF, CK, FH, CF, and OX stands. $\downarrow$ Fine root biomass, $\diamond$ Fine root necromass. 
Table II. Mean fine root biomass and necromass ( $\mathrm{Mg} \mathrm{ha}^{-1}$, mean $\pm \mathrm{SD}$ ) in the NF, CK, FH, CF, and OX stands. Values followed by different letters on the same column indicate significant differences at $P<0.05$.

\begin{tabular}{|c|c|c|c|c|c|c|c|c|c|c|}
\hline \multirow{2}{*}{$\begin{array}{l}\text { Forest } \\
\text { types }\end{array}$} & \multicolumn{4}{|c|}{ Root biomass } & \multicolumn{4}{|c|}{ Root necromass } & \multirow[t]{2}{*}{ Total roots } & \multirow{2}{*}{$\begin{array}{c}\text { Ratio necromass } / \\
\text { biomass }\end{array}$} \\
\hline & 1999 & 2000 & 2001 & Mean & 1999 & 2000 & 2001 & Mean & & \\
\hline \multicolumn{11}{|c|}{ NF, diameter } \\
\hline \multirow[t]{2}{*}{$1-2 \mathrm{~mm}$} & 2.12 & 2.04 & 2.15 & 2.10 & 1.41 & 1.13 & 1.25 & 1.26 & 3.37 & \\
\hline & \pm 0.51 & \pm 0.45 & \pm 0.41 & \pm 0.47 & \pm 0.73 & \pm 0.68 & \pm 0.70 & \pm 0.67 & \pm 0.69 & \\
\hline \multirow[t]{2}{*}{$0.5-1 \mathrm{~mm}$} & 1.44 & 1.39 & 1.44 & 1.42 & 1.16 & 0.97 & 1.07 & 1.07 & 2.49 & \\
\hline & \pm 0.34 & \pm 0.29 & \pm 0.20 & \pm 0.31 & \pm 0.59 & \pm 0.56 & \pm 0.60 & \pm 0.55 & \pm 0.76 & \\
\hline \multirow[t]{2}{*}{$<0.5 \mathrm{~mm}$} & 1.43 & 1.37 & 1.45 & 1.42 & 1.30 & 1.08 & 1.32 & 1.23 & 2.65 & \\
\hline & \pm 0.29 & \pm 0.18 & \pm 0.32 & \pm 0.30 & \pm 0.72 & \pm 0.69 & \pm 0.71 & \pm 0.67 & \pm 0.73 & \\
\hline \multirow[t]{2}{*}{ Subtotal } & 4.99 & 4.80 & 5.04 & 4.94 & 3.87 & 3.18 & 3.64 & 3.56 & 8.51 & 0.72 \\
\hline & \pm 1.06 & \pm 1.08 & \pm 1.03 & $\pm 0.99 \mathrm{a}$ & \pm 1.91 & \pm 1.90 & \pm 1.93 & $\pm 1.85 \mathrm{a}$ & $\pm 1.69 \mathrm{a}$ & \\
\hline \multicolumn{11}{|c|}{$\mathrm{CK}$, diameter } \\
\hline \multirow[t]{2}{*}{$1-2 \mathrm{~mm}$} & 1.39 & 1.47 & 1.53 & 1.47 & 1.00 & 0.99 & 1.04 & 1.01 & 2.48 & \\
\hline & \pm 0.24 & \pm 0.20 & \pm 0.24 & \pm 0.34 & \pm 0.42 & \pm 0.43 & \pm 0.39 & \pm 0.39 & \pm 0.73 & \\
\hline \multirow[t]{2}{*}{$0.5-1 \mathrm{~mm}$} & 0.85 & 0.85 & 0.88 & 0.86 & 0.85 & 0.84 & 0.90 & 0.86 & 1.72 & \\
\hline & \pm 0.11 & \pm 0.12 & \pm 0.12 & \pm 0.21 & \pm 0.39 & \pm 0.39 & \pm 0.34 & \pm 0.35 & \pm 0.60 & \\
\hline \multirow[t]{2}{*}{$<0.5 \mathrm{~mm}$} & 0.84 & 0.88 & 0.91 & 0.87 & 0.86 & 0.86 & 0.91 & 0.88 & 1.75 & \\
\hline & \pm 0.12 & \pm 0.14 & \pm 0.12 & \pm 0.22 & \pm 0.33 & \pm 0.42 & \pm 0.34 & \pm 0.35 & \pm 0.54 & \\
\hline \multirow[t]{2}{*}{ Subtotal } & 3.08 & 3.20 & 3.32 & 3.20 & 2.71 & 2.69 & 2.85 & 2.75 & 5.95 & 0.85 \\
\hline & \pm 0.44 & \pm 0.41 & \pm 0.42 & $\pm 0.41 \mathrm{~b}$ & \pm 1.14 & \pm 1.23 & \pm 0.98 & $\pm 1.05 \mathrm{~b}$ & $\pm 0.91 \mathrm{~b}$ & \\
\hline \multicolumn{11}{|c|}{$\mathrm{FH}$, diameter } \\
\hline \multirow[t]{2}{*}{$1-2 \mathrm{~mm}$} & 0.71 & 0.53 & 0.62 & 0.62 & 0.18 & 0.15 & 0.16 & 0.16 & 0.78 & \\
\hline & \pm 0.10 & \pm 0.12 & \pm 0.10 & \pm 0.13 & \pm 0.05 & \pm 0.06 & \pm 0.04 & \pm 0.05 & \pm 0.14 & \\
\hline \multirow[t]{2}{*}{$0.5-1 \mathrm{~mm}$} & 0.50 & 0.38 & 0.44 & 0.44 & 0.26 & 0.24 & 0.26 & 0.25 & 0.69 & \\
\hline & \pm 0.10 & \pm 0.08 & \pm 0.09 & \pm 0.10 & \pm 0.08 & \pm 0.13 & \pm 0.09 & \pm 0.10 & \pm 0.14 & \\
\hline \multirow[t]{2}{*}{$<0.5 \mathrm{~mm}$} & 1.27 & 0.94 & 1.10 & 1.10 & 1.50 & 1.14 & 1.31 & 1.32 & 2.42 & \\
\hline & \pm 0.30 & \pm 0.14 & \pm 0.21 & \pm 0.26 & \pm 0.48 & \pm 0.28 & \pm 0.34 & \pm 0.39 & \pm 0.53 & \\
\hline \multirow[t]{2}{*}{ Subtotal } & 2.48 & 1.85 & 2.16 & 2.16 & 1.94 & 1.53 & 1.73 & 1.73 & 3.90 & 0.80 \\
\hline & \pm 0.46 & \pm 0.32 & \pm 0.38 & $\pm 0.45 \mathrm{c}$ & \pm 0.60 & \pm 0.45 & \pm 0.46 & $\pm 0.50 \mathrm{c}$ & $\pm 0.75 \mathrm{c}$ & \\
\hline $\mathrm{CF}$, diamet & & & & & & & & & & \\
\hline $1-2 \mathrm{~mm}$ & 0.55 & 0.59 & 0.57 & 0.57 & 0.38 & 0.35 & 0.37 & 0.36 & 0.93 & \\
\hline & \pm 0.10 & \pm 0.15 & \pm 0.12 & \pm 0.12 & \pm 0.10 & \pm 0.10 & \pm 0.08 & \pm 0.10 & \pm 0.24 & \\
\hline $0.5-1 \mathrm{~mm}$ & 0.28 & 0.26 & 0.27 & 0.27 & 0.36 & 0.29 & 0.32 & 0.33 & 0.59 & \\
\hline & \pm 0.11 & \pm 0.06 & \pm 0.10 & \pm 0.09 & \pm 0.10 & \pm 0.08 & \pm 0.08 & \pm 0.09 & \pm 0.19 & \\
\hline$<0.5 \mathrm{~mm}$ & 0.67 & 0.62 & 0.64 & 0.64 & 0.64 & 0.56 & 0.61 & 0.60 & 1.25 & \\
\hline & \pm 0.23 & \pm 0.18 & \pm 0.21 & \pm 0.20 & \pm 0.17 & \pm 0.13 & \pm 0.13 & \pm 0.13 & \pm 0.21 & \\
\hline Subtotal & 1.51 & 1.46 & 1.48 & 1.48 & 1.37 & 1.20 & 1.29 & 1.29 & 2.77 & 0.87 \\
\hline & \pm 0.39 & \pm 0.32 & \pm 0.35 & $\pm 0.34 \mathrm{~d}$ & \pm 0.35 & \pm 0.29 & \pm 0.26 & $\pm 0.32 \mathrm{~d}$ & $\pm 0.62 \mathrm{~d}$ & \\
\hline OX, diamet & & & & & & & & & & \\
\hline $1-2 \mathrm{~mm}$ & 0.46 & 0.56 & 0.52 & 0.51 & 0.30 & 0.25 & 0.27 & 0.27 & 0.79 & \\
\hline & \pm 0.20 & \pm 0.17 & \pm 0.52 & \pm 0.18 & \pm 0.11 & \pm 0.11 & \pm 0.33 & \pm 0.12 & \pm 0.42 & \\
\hline $0.5-1 \mathrm{~mm}$ & 0.39 & 0.38 & 0.39 & 0.39 & 0.29 & 0.26 & 0.26 & 0.27 & 0.66 & \\
\hline & \pm 0.17 & \pm 0.14 & \pm 0.62 & \pm 0.15 & \pm 0.13 & \pm 0.13 & \pm 0.30 & \pm 0.11 & \pm 0.60 & \\
\hline$<0.5 \mathrm{~mm}$ & 0.83 & 0.79 & 0.79 & 0.80 & 0.86 & 0.65 & 0.78 & 0.76 & 1.56 & \\
\hline & \pm 0.18 & \pm 0.17 & \pm 0.55 & \pm 0.53 & \pm 0.12 & \pm 0.11 & \pm 0.32 & \pm 0.31 & \pm 0.43 & \\
\hline Subtotal & 1.68 & 1.73 & 1.70 & 1.70 & 1.45 & 1.16 & 1.31 & 1.31 & 3.01 & 0.77 \\
\hline & \pm 0.78 & \pm 0.87 & \pm 0.80 & $\pm 0.77 \mathrm{~d}$ & \pm 0.54 & \pm 0.56 & \pm 0.54 & $\pm 0.52 \mathrm{~d}$ & $\pm 0.47 \mathrm{~d}$ & \\
\hline
\end{tabular}



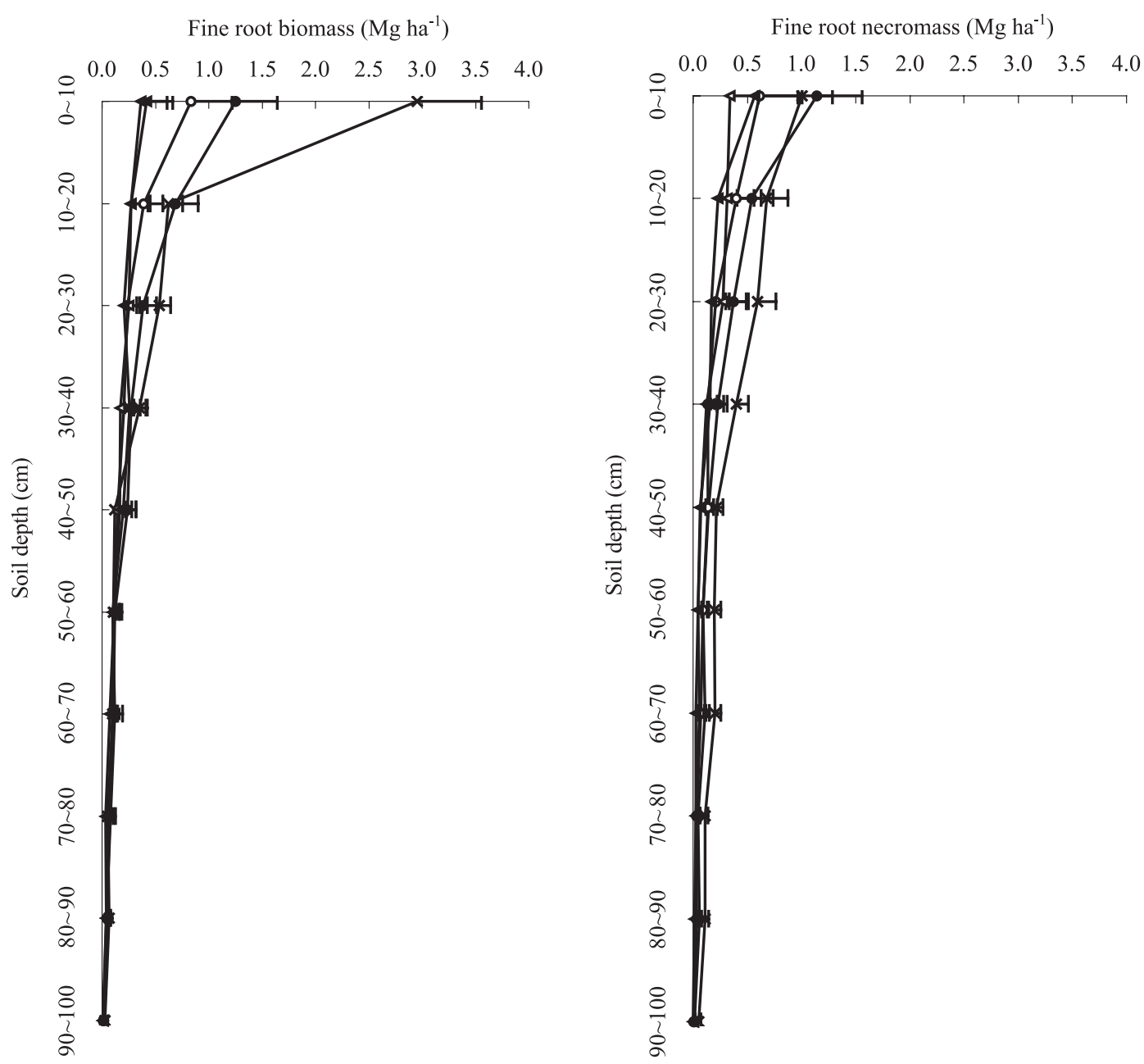

Figure 3. Depth distribution of fine root biomass and necromass in the NF, CK, FH, CF, and OX stands $(\times \mathrm{NF} ; \bullet \mathrm{CK} ; \mathrm{O} \mathrm{FH} ; \triangle \mathrm{CF} ; \boldsymbol{\Delta} \mathrm{OX})$.

FH, CF and OX, respectively (Fig. 3). While for root necromass, differences of superficial soil were less announceable. For the $\mathrm{NF}, 59.8 \%$ of root biomass was found in the top $0-10 \mathrm{~cm}$ layer, compared with $39.1 \%, 38.5 \%, 24.5 \%$ and $24.4 \%$ in the $\mathrm{CK}, \mathrm{FH}$, $\mathrm{CF}$, and OX stand, respectively.

\subsection{Fine root production and mortality}

Percentages of original mass lost after the first year of decomposition ranged from $43.8 \sim 56.3 \%$ for the $\mathrm{FH}$ to $68.3 \sim$ $80.1 \%$ for the NF. Roots with a larger diameter had a lower rate of mass loss $(P<0.05)$ (Tab. III). The negative exponential decay model showed a good fit for the decay pattern for all species and regressions were highly significant $\left(r^{2}>0.9, P<0.05\right)$. Mean annual root decomposition, mortality, and production ranged from $8.470,8.632$, and $9.5 \mathrm{Mg} \mathrm{ha}^{-1} \mathrm{a}^{-1}$ in the NF to 2.503, 2.492, and $2.513 \mathrm{Mg} \mathrm{ha}^{-1} \mathrm{a}^{-1}$ in the CF stand, and could be ranked as NF $>\mathrm{CK}>\mathrm{FH}>\mathrm{OX}>\mathrm{CF}$ (Tab. IV). The mean residence time varied from $0.56 \mathrm{a}$ in the $\mathrm{NF}$ to $0.68 \mathrm{a}$ in the $\mathrm{FH}$.

\section{DISCUSSION}

\subsection{Fine root biomass}

The published values of fine root biomass of the world subtropical forests ranged between 1.1 to $10.6 \mathrm{Mg} \mathrm{ha}^{-1}[16,17,36$, $37,39]$. The mean fine root biomass in the NF was in the upper part of this range, and lied in the middle of the range recorded for the tropical broadleafs evergreen forests $\left(0.6 \sim 22.7 \mathrm{Mg} \mathrm{ha}^{-1}\right)$ [36]. The fine root biomass in the four plantations was lower than that in the NF, but similar to that recorded in climatically comparable plantations $[17,36,39]$. Further, the fine root biomass estimate of the FH was higher than those of other subtropical needle evergreen stands [17, 36, 39]. The higher soil fertility, productivity, and species diversity levels in the NF, compared with the monoculture plantations, may explain the higher fine root biomass in the NF (Tab. I).

Rapid recovery of fine root biomass to pre-disturbance levels has been found in some regenerated forests [27, 44], while 
Table III. Mass loss rates after the second year of decomposition and the decomposition constant of fine roots in the NF, CK, FH, CF, and OX stands (litter-bag method).

\begin{tabular}{lccccc}
\hline $\begin{array}{l}\text { Forest } \\
\text { type }\end{array}$ & $\begin{array}{c}\text { Diameter } \\
\text { class } \\
(\mathrm{mm})\end{array}$ & $\begin{array}{c}\text { Mass loss rate } \\
\text { after 2nd year } \\
(\%)\end{array}$ & $\begin{array}{c}95 \% \text { decay } \\
\text { time } \\
(\mathrm{d})\end{array}$ & $\begin{array}{c}\text { Decomposition } \\
\text { constant }\end{array}$ \\
\cline { 5 - 6 } & & & & & \multicolumn{2}{c}{ (day $\left.^{-1}\right)$} & $\left(\right.$ year $\left.^{-1}\right)$ \\
\hline $\mathrm{NF}$ & $1-2$ & 90 & 936 & 0.0032 & 1.17 \\
& $0.5-1$ & 94 & 768 & 0.0039 & 1.42 \\
& $<0.5$ & 96.1 & 666 & 0.0045 & 1.64 \\
$\mathrm{CK}$ & $1-2$ & 86.7 & 1070 & 0.0028 & 1.02 \\
& $0.5-1$ & 93.5 & 788 & 0.0038 & 1.39 \\
& $<0.5$ & 95.1 & 713 & 0.0042 & 1.53 \\
FH & $1-2$ & 68.4 & 1872 & 0.0016 & 0.58 \\
& $0.5-1$ & 74.5 & 1577 & 0.0019 & 0.69 \\
& $<0.5$ & 80.9 & 1302 & 0.0023 & 0.84 \\
CF & $1-2$ & 72.6 & 1664 & 0.0018 & 0.66 \\
& $0.5-1$ & 79.5 & 1362 & 0.0022 & 0.80 \\
& $<0.5$ & 84.6 & 1152 & 0.0026 & 0.95 \\
OX & $1-2$ & 87.6 & 1033 & 0.0029 & 1.06 \\
& $0.5-1$ & 94 & 768 & 0.0039 & 1.42 \\
& $<0.5$ & 95.1 & 713 & 0.0042 & 1.53 \\
\hline & & & & &
\end{tabular}

other studies have shown a gradual increase in fine root growth and biomass up to at least 20 years following forest removal [2]. Here, however, none of the four plantations had their fine root biomass up to $70 \%$ of those in the NF after 33 years of forest conversion. The reduction in fine root occupancy in the monoculture plantations, compared with in the natural forest, might be due to the mono-species, frequent land disturbance, and high nutrient loss before canopy closure during the early stage in the plantations [18, 41-43].

\subsection{Seasonal pattern}

The seasonal pattern in fine roots may be attributed to changes in soil moisture and soil temperature [12, 19, 21]. Studies of the seasonal variations in root biomass have reported tree stands showing no distinct seasonal pattern [24] and those with one [22] or two [11] statistically significant peaks. Peaks in standing fine root biomass have been measured in spring [6, 11], summer [6], and fall [34] in temperate climates.

There was detected in these stands a peak of fine root biomass in March, a period prior to an active growth of aboveground part for most tree species in subtropical China. This early spring flush of fine root growth might result, not only from the increase of soil temperature and soil humidity (due to initiation of rainy season), but also from an abundant supply of carbohydrates reserved during the former growing season [19, 21]. In the $\mathrm{CF}$, and in a lesser intensity, in $\mathrm{FH}$, another high value of fine root biomass occurred in September, which might

Table IV. Annual fine root production, mortality and decomposition and turnover rates in the NF, CK, FH, CF, and OX stands.

\begin{tabular}{|c|c|c|c|c|c|c|}
\hline Forest type & Year & $\begin{array}{c}\text { Decomposition } \\
\left(\mathrm{Mg} \mathrm{ha}^{-1} \mathrm{a}^{-1}\right)\end{array}$ & $\begin{array}{c}\text { Mortality } \\
\left(\mathrm{Mg} \mathrm{ha}^{-1} \mathrm{a}^{-1}\right)\end{array}$ & $\begin{array}{c}\text { Production } \\
\left(\mathrm{Mg} \mathrm{ha}^{-1} \mathrm{a}^{-1}\right)\end{array}$ & $\begin{array}{c}\text { Turnover rate } \\
\qquad\left(a^{-1}\right)\end{array}$ & $\begin{array}{c}\text { Mean residence } \\
\text { time (a) }\end{array}$ \\
\hline \multirow[t]{4}{*}{$\mathrm{NF}$} & 1999 & 9.23 & 7.89 & 8.83 & 1.97 & \\
\hline & 2000 & 7.92 & 8.48 & 8.06 & 1.68 & \\
\hline & 2001 & 9.09 & 9.53 & 9.50 & 1.89 & \\
\hline & Mean & 8.75 & 8.63 & 8.80 & 1.78 & 0.56 \\
\hline \multirow[t]{4}{*}{ CK } & 1999 & 4.89 & 4.59 & 5.95 & 1.94 & \\
\hline & 2000 & 5.00 & 5.65 & 5.41 & 1.69 & \\
\hline & 2001 & 5.14 & 5.21 & 4.91 & 1.48 & \\
\hline & Mean & 5.01 & 5.15 & 5.42 & 1.70 & 0.59 \\
\hline \multirow[t]{4}{*}{$\mathrm{FH}$} & 1999 & 3.64 & 3.78 & 3.40 & 1.37 & \\
\hline & 2000 & 2.85 & 2.79 & 2.96 & 1.60 & \\
\hline & 2001 & 3.23 & 3.23 & 3.24 & 1.51 & \\
\hline & Mean & 3.24 & 3.26 & 3.20 & 1.48 & 0.68 \\
\hline \multirow[t]{4}{*}{$\mathrm{CF}$} & 1999 & 2.65 & 2.57 & 2.73 & 1.81 & \\
\hline & 2000 & 2.33 & 2.39 & 2.26 & 1.54 & \\
\hline & 2001 & 2.53 & 2.52 & 2.55 & 1.72 & \\
\hline & Mean & 2.50 & 2.49 & 2.51 & 1.69 & 0.59 \\
\hline \multirow[t]{4}{*}{ OX } & 1999 & 2.96 & 2.95 & 2.85 & 1.69 & \\
\hline & 2000 & 2.36 & 2.37 & 2.44 & 1.41 & \\
\hline & 2001 & 2.67 & 2.67 & 2.65 & 1.56 & \\
\hline & Mean & 2.66 & 2.66 & 2.65 & 1.55 & 0.65 \\
\hline
\end{tabular}


be associated with an increase of soil moisture, after the dry, hot August [43, 45]. During the warm summer, the soil water content could be very low due to high evapotranspiration and a decrease of rainfall occurred usually on July (Fig. 1). Thus, the fine roots, in particular, may have subsequently suffered from drought, e.g., the low rainfall in June 1999, May and July 2000, and July 2001 has resulted in a low level of fine root biomass in the NF, CK, FH, and CF at the May or July sampling dates (compare Figs. 1 and 2). Surprisingly, roots of the OX seemed to show no response to monthly rainfall. The decline in fine root biomass during the winter season may, at least in part, be mainly related to low temperature conditions. This seasonal pattern of fine root biomass (maximum in early spring and minimum in dry summer and in cold winter) observed in the present study were also found by Liao et al. [17], Wen et al. [37] and Li et al. [16] in subtropical China.

\subsection{Vertical distribution}

Fine root distribution decreasing with soil depth in the present study was similar to those in many forest ecosystems $[3,9,20,21,25,41]$. This may reflect the distribution of nutrients returned to the soil by litterfall, canopy leachates and stemflow, and the trophotaxis of fine roots. Ford and Deans [9] stated that high concentration of fine roots in the surface soil layers of the forest are related to higher nutrient concentrations if there is enough moisture, because the decomposition of the organic litter and release of nutrients on the surface soil, particularly during periods of active growth. The leaf litter forms a shelter for the surface roots by providing a microclimate, if rainfall is not limiting, for the development of new roots. Also this organic litter is the chief source for nutrients to be recycled.

A significant difference of fine root biomass existed in the top $10 \mathrm{~cm}$ layer between the NF and the plantations, which might be ascribed to a higher nutrient availability in the topsoil of the NF (Tab. I) due to a higher amount of organic matter and nutrients derived from litterfall, and a faster litter decay rate (Tab. I) as well [40]. Further, the high concentration of fine root biomass in the topsoil can much benefit the soil fertility by ways of root exudates, formation of root channel, and return of organic mass and nutrients through root turnover. Thus, the topsoil of the NF was characteristic by low soil bulk-density, high aggregate stability [42], and high level of SOM and nutrients (Tab. I). However, differences of root distribution among the four plantations were relatively low and might be mainly related to the differences of tree characteristics.

The subtropical forests of China are in the risk of nutrient loss due to high annual rainfall, steep slopes, and fragile soils (note the acid soil $\mathrm{pH}$; Tab. I). Thus, in this context, the native forests are dependent upon tight recycling of nutrients [46]. The fine root system that has developed in the surface layer of the soil, and that particularly located in the upper $10 \mathrm{~cm}$ layer (Fig. 3), should facilitate rapid uptake of nutrients released by decomposing litter. In addition, nutrients included in throughfall plus stemflow would also be intercepted by the roots. The presence of fine root biomass up to $2.96 \mathrm{Mg} \mathrm{ha}^{-1}$ in the top $10 \mathrm{~cm}$ soil of the NF is, therefore, much helpful in mopping up the nutrients. During the conversion of native forests to managed plantations, clear-cutting, slash-burning, soil preparing, and intensive tending, etc, are commonly applied, and the topsoil are frequently disturbed and nutrient and surface soil loss would become very serious [43]. A rapid recovery of uppermost root distribution is, therefore, of very much importance in helping nutrient conservation. As indicated in the present study, a reduction in the occurrence of fine roots in the uppermost $10 \mathrm{~cm}$ of the soil profile in the plantation forests, compared with in the NF, would bring a risk of nutrient loss, especially during the early growth stage.

\subsection{Fine root productivity and turnover}

Though the soil conditions differed between the NF and the CK (Tab. I), the decomposition rates of the fine roots of $C$. kawakamii was very similar (Tab. III), indicated that here climate drives the decomposition and there was little chemical composition and site effect on root decomposition. It is also can be found that the decay rates of broadleaves ( $C$. kawakamii and O. xylocarpa) were much higher than those of conifers (F. hodginsii and $C$. lanceolata), which were also reported by Liao et al. [17] and Usman et al. [32]. However, whether it is a common conclusion depends on a large database. The decay rates of $F$. hodginsii and $C$. lanceolata were much higher than those estimated for other conifers, e.g., by McClaugherty et al. [22] for red pine (12-25\%); Berg [4] for Scot pine (25\%); Fogel and Hunt [8] for Douglas fir (15\%), and by Usman et al. [32] for Pinus roxburghii (26\%). The values of annual decay constant ( $k$, year-based; calculated by the negative exponential model) fall in the range reported across the world (0.02-1.74) $[2,5,8$, $17,22,29,31,33]$, and were comparable with the values for other subtropical forests (0.6-1.74) [2, 5, 17].

The most commonly used method of estimating fine root production and mortality involves periodic measurements of live, and in some cases dead, fine root biomass. Publivcover and Vogt [25] compared three methods (the max-min, decision matrix, and compartment flow methods) for estimating forest fine root production. In their results, the compartment-flow method was the most accurate and overcomes the problems of underestimation of production to which the biomass-only methods are subject. Though difference in estimation method (Tab. V), fine root production in the NF was much higher than those in a mixed needle-broadleaf evergreen forest and a broadleaf evergreen forest in the Dinghushan in southern subtropical China (2.42-2.65 Mg ha $\left.{ }^{-1} \mathrm{a}^{-1}\right)$ [37] and a Castanopsis eyrei forest (7.37 $\mathrm{Mg} \mathrm{ha}^{-1} \mathrm{a}^{-1}$ ) in Wuyi Mountain in mid-subtropical China [16]. Further, the value of the NF was similar to that of a tropical evergreen forest $\left(6.3-9.4 \mathrm{Mg} \mathrm{ha}^{-1} \mathrm{a}^{-1}\right)$ in the Western Ghats, South India [30] (Tab. V). Root production in the CK was lower than that in the NF, but higher than that recorded in tree plantations of the same climate [17, 36, 39]. The FH had a root production higher than other subtropical needleleaf evergreen forests, and the estimate of the CF was close to those of Chinese fir plantations in Huitong and Fujian [17, 36, 39]. Particularly, the root production in the $\mathrm{OX}\left(2.65 \mathrm{Mg} \mathrm{ha}^{-1} \mathrm{a}^{-1}\right)$ was very similar to that in the $\mathrm{CF}\left(2.51 \mathrm{Mg} \mathrm{ha}^{-1} \mathrm{a}^{-1}\right)$ in the present study, and rather low compared with that found in a broadleaved plantation of Michelia macclurei in Huitong (4.32 $\mathrm{Mg} \mathrm{ha}^{-1} \mathrm{a}^{-1}$ ) (Tab. V) [17]. However, the measurement of true decay rates is the biggest obstacle to accurate estimation of fine root production when using the compartment-flow method. In the present study, a constant decay rate (measured in early summer, 
Table V. Fine root productivity in various forest ecosystems.

\begin{tabular}{|c|c|c|c|c|c|c|c|}
\hline Forest type & Climate & $\begin{array}{l}\text { Stand age } \\
\text { (a) }\end{array}$ & $\begin{array}{l}\text { Root diameter } \\
\qquad(\mathrm{mm})\end{array}$ & $\begin{array}{l}\text { Sampling soil } \\
\text { depth }(\mathrm{cm})\end{array}$ & $\begin{array}{l}\text { Root production } \\
\left(\mathrm{Mg} \mathrm{ha}^{-1} \mathrm{a}^{-1}\right)\end{array}$ & Method & Source \\
\hline Pure forest of $C$. lanceolata & Northern subtropics & 11 & $<2$ & 45 & 1.14 & Max-min & {$[16]$} \\
\hline Pure forest of Michelia macclurei & Northern subtropics & 11 & $<2$ & 45 & 4.32 & Max-min & [16] \\
\hline $\begin{array}{l}\text { Mixed forest of } C \text {. lanceolata } \\
\text { and } M . \text { macclurei }\end{array}$ & Northern subtropics & 11 & $<2$ & 45 & 2.18 & $\operatorname{Max}-\min$ & {$[16]$} \\
\hline Castanopsis eyrei & Mid-subtropics & 76 & $<2$ & 40 & 7.37 & Ingrowth core & {$[15]$} \\
\hline C. lanceolata & Mid-subtropics & 27 & $<2$ & 100 & 2.50 & Max-min & [37] \\
\hline \multirow[t]{2}{*}{ Natural forest of C. kawakamii } & Mid-subtropics & $\sim 150$ & $<2$ & 20 & $6.37^{*}$ & $\begin{array}{l}\text { Compartment } \\
\text { flow model }\end{array}$ & $\begin{array}{l}\text { The present } \\
\text { study }\end{array}$ \\
\hline & & & & 40 & $7.95 *$ & $\begin{array}{l}\text { Compartment } \\
\text { flow model }\end{array}$ & $\begin{array}{l}\text { The present } \\
\text { study }\end{array}$ \\
\hline C. kawakamii & Mid-subtropics & 33 & $<2$ & 40 & $4.41 *$ & $\begin{array}{l}\text { Compartment } \\
\text { flow model }\end{array}$ & $\begin{array}{c}\text { The present } \\
\text { study }\end{array}$ \\
\hline F. hodginsii & Mid-subtropics & 33 & $<2$ & 40 & $2.53^{*}$ & $\begin{array}{l}\text { Compartment } \\
\text { flow model }\end{array}$ & $\begin{array}{l}\text { The present } \\
\text { study }\end{array}$ \\
\hline C. lanceolata & Mid-subtropics & 33 & $<2$ & 40 & $1.79 *$ & $\begin{array}{l}\text { Compartment } \\
\text { flow model }\end{array}$ & $\begin{array}{l}\text { The present } \\
\text { study }\end{array}$ \\
\hline O. xylocarpa & Mid-subtropics & 33 & $<2$ & 40 & $1.91 *$ & $\begin{array}{l}\text { Compartment } \\
\text { flow model }\end{array}$ & $\begin{array}{l}\text { The present } \\
\text { study }\end{array}$ \\
\hline $\begin{array}{l}\text { Monsoon evergreen, } \\
\text { broad-leaved forest }\end{array}$ & Southern-subtropics & - & $<2$ & 40 & 2.65 & Max-min & {$[36]$} \\
\hline $\begin{array}{l}\text { Mixed coniferous and } \\
\text { broad-leaved forest }\end{array}$ & Southern-subtropics & - & $<2$ & 40 & 2.42 & Advanced max-min & {$[36]$} \\
\hline Moist deciduous forest & Tropics & - & $<3$ & 25 & $8.30-8.90$ & $\begin{array}{l}\text { Summa of positive } \\
\text { biomass increments }\end{array}$ & [29] \\
\hline Semi-evergreen forest & Tropics & - & $<3$ & 25 & $7.90-8.04$ & $\begin{array}{l}\text { Summa of positive } \\
\text { biomass increments }\end{array}$ & [29] \\
\hline Evergreen forest & Tropics & - & $<3$ & 25 & $6.30-9.40$ & $\begin{array}{l}\text { Summa of positive } \\
\text { biomass increments }\end{array}$ & [29] \\
\hline
\end{tabular}

* Productivity of fine roots at different soil depths was calculated according to their respective biomass proportion in total fine root biomass.

which might represent an overestimate of mean value of a year) were used with this method, thus, the failure to account for the temperature-dependency of decay rate might cause an overestimate of root turnover [14].

Forest conversion has reduced fine root production by $71 \%$ in the $\mathrm{CF}$ to $38 \%$ in the $\mathrm{CK}$, and reduced fine root mortality by $71 \%$ in the CF to $40 \%$ in the CK. Given the relevance of fine root inputs for SOM dynamics, this may represent a substantial decrease in organic $\mathrm{C}$ flow into the soil. The intensity and permanence of the change in $\mathrm{C}$ inputs is an important land-use issue that deserves further quantification.

In these forests, mean annual fine root production was nearly balanced by mean annual mortality, which indicated that there was little net growth of fine root systems, i.e., it is close to equilibrium; the annual root production was largely used to annual root litter production [19]. Studies have indicated that fine root litter production is similar in magnitude to, or higher, than foliar litter production $[13,23]$. In these forests, the mean annual litterfall was $11.01,9.54,7.29,5.46$, and $5.69 \mathrm{Mg} \mathrm{ha}^{-1} \mathrm{a}^{-1}$ for the $\mathrm{NF}, \mathrm{CK}, \mathrm{FH}, \mathrm{CF}$, and OX, respectively [40]. Thus, the ratio of root litter production to the aboveground litter production ranged from 0.45 in the $\mathrm{FH}$ to 0.78 in the NF. Raich and Nadelhoffer [26] indicated that fine root litter production is positively related to aboveground litterfall across world forests. A significant correlation between the two components could also be deduced from our results $(r=0.896 ; P=0.015 ; n=5)$.

According to Gill and Jackson [10], fine root turnover rates of world forests were in the range of 0.02 to $2.64 \mathrm{a}^{-1}$, with an average of $0.56 \mathrm{a}^{-1}$. Our estimates $\left(1.48 \sim 1.78 \mathrm{a}^{-1}\right.$; Tab. IV) fall in the world range and were significant higher than the global average, which might be due to the higher temperature of our study site (Fig. 1). Also, our values were much higher than those of other subtropical forests [16, 17, 37, 39].

\section{CONCLUSION}

Conversion of native forest to tree plantations have reduced fine root biomass in the soil profile, especially in the uppermost $10 \mathrm{~cm}$ soil layer, which would increase the risk of nutrient availability. Also, a decreased in fine root productivity and turnover, coupled to the decrease in aboveground litter production due 
to forest transformation, may have important consequences for C sequestration (lower SOM content), nutrient availability, and then for long-term site productivity. In this context, forest managements which contribute to a rapid occupancy of topsoil by fine roots should be introduced in monoculture reafforestation.

Acknowledgements: This work was funded by the National Natural Science Foundation of China (30170770), the Teaching and Research Award program for MOE P.R.C. (TRAPOYT), the Key Basic Research Project of Fujian Province (2000F004), and the Natural Science Foundation of Fujian Province (B0110025).

\section{REFERENCES}

[1] Aber J.D., Melillo J.M., Fine root turnover in forest ecosystems in relation to quality and form of nitrogen availability: a comparison of two methods, Oecologia 66 (1985) 317-321.

[2] Arunachalam A., Pandey H.N., Tripathi R.S., Maithani K., Fine root decomposition and nutrient mineralization patterns in a subtropical humid forest following tree cutting, For. Ecol. Manage. 86 (1996) 141-150.

[3] Bennett J.N., Andrew B., Prescott C.E., Vertical fine root distributions of western redcedar, western hemlock, and salal in old-growth cedar-hemlock forests on northern Vancouver island, Can. J. For. Res. 32 (2002) 1208-1216.

[4] Berg B., Staaf H., Decomposition rate and chemical changes of Scots pine needle litter. II. Influence of chemical composition structure and function of Northern Coniferous forests- an ecosystem study, Ecol. Bull. 32 (1981) 373-390.

[5] Bloomfield J., Vogt K.A., Vogt D.J., Decay rate and substrate quality of fine roots and foliage of two tropical tree species in the Luquillo Experimental Forest, Puerto Rico, Plant Soil 150 (1993) 233-245.

[6] Burton A.J., Pregitzer K.S., Hendrick R.L., Relationships between fine root dynamics and nitrogen availability in Michigan northern hardwood forests, Oecologia 125 ( 2000) 389-399.

[7] Castellanos J., Jaramillo V.J., Sanford R.B. Jr., Kauffman J.B., Slash- and -burning effects on fine root biomass and productivity in a tropical dry forest ecosystem in Mexico, For. Ecol. Manage. 148 (2001) 41-50.

[8] Fogel R., Hunt G., Fungal and arboreal biomass in a western Oregon Douglar-fir ecosystem. Distribution patterns and turnover, Can. J. For. Res. 9 (1979) 245-256.

[9] Ford E.D., Deans J.D., Growth of a sitka spruce plantation: spatial distribution and seasonal fluctuations of lengths, weights and carbohydrate concentrations of fine roots, Plant Soil 47 (1977) 463 485 .

[10] Gill R.A., Jackson R.B., Global patterns of root turnover for terrestrial ecosystems, New Phytol. 147 (2000) 13-31.

[11] Grier C.C., Vogt K.A., Keys M.R., Edmonds R.L., Biomass distribution and above and below ground production in a young and mature Abies amabilis zone ecosystems of the Washington cascades, Can. J. For. Res. 11 (1981) 155-167.

[12] Hook P.B., Lauenroth W.K., Burke I.C., Spatial patterns of roots in a semiarid grassland: abundance of canopy openings and regeneration gaps, J. Ecol. 82 (1994) 485-494.

[13] Joslin J.D., Henderson G.S., Organic matter and nutrients associated with fine root turnover in a white oak stand, For. Sci. 33 (1987) 330-346.

[14] Kurz W.A., Kimmins J.P., Analysis of some sources of error in methods used to determine fine root production in forest ecosystems: a simulation approach, Can. J. For. Res. 17 (1987) 909-912.

[15] Le Goff N., Ottorini J.M., Root biomass and biomass increment in a beech (Fagus sylvatica L.) stand in North-East France, Ann. For. Sci. 58 (2001) 1-13.
[16] Li L.H., Lin P., Xing X.R., Fine root biomass and production of Castanopsis eytei forests in Wuyi Mountains, Chin. J. Appl. Ecol. 9 (1998) 337-340 (in Chinese, with English abstract).

[17] Liao L.P., Chen C.Y., Zhang J.W., Turnover of fine roots in pure and mixed Cunninghamia lanceolata and Michelia macclurei forests, Chin. J. Appl. Ecol. 6 (1995) 7-10 (in chinese, with english abstract).

[18] Lin P., Qiu X.Z., Study on the Castanopsis kawakamii forest in the Wakeng area of Sanming city, Fujian province, Acta Phytoecol. Geobot. Sinica 10 (1986) 241-252 (in Chinese, with English abstract).

[19] López B., Sabaté S., Gracia C.A., Annual and seasonal changes in fine root biomass of Quercus ilex L., Plant Soil 230 (2001) 125 134.

[20] López B., Sabaté S., Gracia C.A., Vertical distribution of fine root density, length density, area index and mean diameter in a Quercus ilex forest, Tree Physiol. 21 (2001) 555-560.

[21] Makkonen K., Helmisaari H.S., Seasonal and yearly variations of fine root biomass and necromass in a Scots pine (Pinus sylvestris L.) stand, For. Ecol. Manage. 102 (1998) 283-290.

[22] McClaugherty C.A., Aber J.D., Melillo J.M., The role of fine roots in the organic matter and nitrogen budgets of two forested ecosystems, Ecology 63 (1982) 1481-1490.

[23] McClaugherty C.A., Aber J.D., Mellilo J.M., Decomposition dynamics of fine roots in forested ecosystems, Oikos 42 (1984) 378386.

[24] Persson H., Root dynamics in a young Scots pine stand in central Sweden, Oikos 30 (1978) 508-519.

[25] Publicover D.A., Vogt K.A., A comparison of methods for estimating forest fine root production with respect to sources of error, Can. J. For. Res. 23 (1993) 1179-1186.

[26] Raich J.W., Nadelhoffer K.J., Belowground carbon allocation in forest ecosystems: global trends, Ecology 70 (1989) 1346-1354.

[27] Raich J., Fine roots regrow rapidly after forest felling, Biotropica 12 (1980) 231-232.

[28] Santantonio D., Hermann R.K., Standing crop production, and turnover of fine roots on dry, moderate, and wet sites of mature Douglas-fir in western Oregon, Ann. Sci. For. 42 (1985) 113-142.

[29] Shan J.P., Tao D.L., Wang S., Study on fine root turnover in mixed forest of broadleaved and Korea pine in Changbai Mountain, Chin. J. Appl. Ecol. 4 (1993) 241-245 (in Chinese, with English abstract).

[30] Sundarapandian S.M., Swamy P.S., Fine root biomass distribution and productivity patterns under open and closed canopies of tropical forest ecosystems at Kodayar in Western Ghats, South India, For. Ecol. Manage. 86 (1996) 181-192.

[31] Tripathi S.K., Singh K.P., Nutrient immobilization and release patterns during plant decomposition in a dry tropical bamboo savanna, India, Biol. Fertil. Soils 14 (1992) 191-199.

[32] Usman S., Singh S.P., Rawat Y.S., Bargali S.S., Fine root decomposition and nitrogen mineralisation patterns in Quercus leucotrichophora and Pinus roxburghii forests in central Himalaya, For. Ecol. Manage. 131 (2000) 191-199.

[33] Van Vuuren M.M.I., Berendse F., De Visser W., Species and site differences in the decomposition of litter and roots from wet heathlands, Can. J. Bot. 71 (1993) 167-173.

[34] Vogt K.A., Edmonds R.L., Grier C.C., Seasonal changes in biomass and vertical distribution of mycorrhizal and fibrous-textured conifer roots in 23- and 180-year-old Abies amabilis stands, Can. J. For. Res. 11 (1981) 223-229.

[35] Vogt K.A., Grier C.C., Vogt D.J., Production, turnover, and nutrient dynamics of above- and belowground detritus of world forests, Adv. Ecol. Res. 15 (1986) 303-377.

[36] Vogt K.A., Vogt D.J., Palmiotto P.A., Boon P., O’Hara J., Asbjornsen H., Review of root dynamics in forest ecosystems grouped by climate, climatic forest type and species, Plant Soil 187 (1996) 159219 . 
[37] Wen D.Z., Wei P., Kong G.H., The productivity and turnover of fine roots of southern subtropical forest in Dinghu Mountains, Acta Bot. Sin. 23 (1999) 361-369 (in Chinese, with English abstract).

[38] Yang Y.S., Chen G.S., Guo J.F., Lin P., Decomposition dynamic of fine roots in a mixed forest of Cunninghamia lanceolata and Tsoongiodendron odorum in mid-subtropics, Ann. For. Sci. 61 (2004) $65-72$.

[39] Yang Y.S., Chen G.S., He Z.M., Chen Y.X., Guo J.F., Production, distribution and nutrient return of fine roots in a mixed and a pure forest in subtropical China, Chin. J. Appl. Environ. Biol. 8 (2002) 223-233.

[40] Yang Y.S., Guo J.F., Chen G.S., Xie J.S., Cai L.P., Lin P., Litterfall, nutrient return, and leaf-litter decomposition in four plantations compared with a natural forest in subtropical China, Ann. For. Sci. 61 (2004) 465-476.

[41] Yang Y.S., Guo J.F., Chen G.S., He Z.M., Xie J.S., Effects of slash burning on nutrient removal and soil fertility in Chinese fir and evergreen broadleaved forests of mid-subtropical China, Pedosphere 13 (2003) 87-96.

[42] Yang Y.S., Li Z.W., Liu A.Q., Studies on soil fertility for natural forest of Castanopsis kawakamii replaced by broadleaf plantation, J. Northeast For. Univ. 21 (1993) 14-21 (in Chinese, with English abstract).

[43] Yang Y.S., Studies on the sustainable management of Chinese fir plantations, China Forestry Publishing House, Beijing, 1998 (in Chinese)

[44] Yin X., Pery J.A., Dixon R.K., Fine-root dynamics and biomass distribution in a Quercus ecosystem after harvest, For. Ecol. Manage. 27 (1989) 159-177.

[45] Yu X.T., Silviculture of Chinese fir, Fujian Science and Technology Press, Fuzhou, 1996, pp. 24-35 (in Chinese).

[46] Zhang H.B., Forests in Fujian, China Forestry Publishing House, Beijing, 1993 (in Chinese). 